\title{
O PERDÃo NA CONDIÇÃO HUMANA: BREVES PERSPECTIVAS DE UMA RELEITURA DO EVANGELHO em Hanna Arendt
}

\author{
Helerson Alves Nogueira* \\ Felipe da Silveira Costa**
}

\begin{abstract}
RESUMO
0 presente trabalho tem como objetivo apresentar a noção do perdão que Hannah Arendt desenvolve no capítulo 5 do livro $A$ condição Humana, em especial, no subcapítulo "A irreversibilidade e o poder de perdoar". Para Arendt, Jesus de Nazaré foi o descobridor do papel do perdão na arena do espaço público. Antes de apresentar os motivos pelos quais Arendt menciona alguns textos do Novo Testamento, será necessário compreender o contexto político que a impulsionou escrever: a descoberta que para os regimes totalitários, os homens são supérfluos. As "fábricas de morte" são laboratórios que tentam modificar a natureza humana. A teologia cristã é requisitada por Arendt para responder uma questão encontrada já nas últimas páginas das Origens do Totalitarismo: Há perdão para qualquer tipo de ação? Há perdão para o que não se pode punir e punição para o que não se pode perdoar? Das páginas do Novo Testamento, Arendt encontra inspiração para refletir sobre tais circunstâncias.

Palavras-chave: Perdão. Totalitarismo. Ação. Espaço público. Jesus. Liberdade. Política.
\end{abstract}

* Mestre e Doutorando em Ciências da Religião pelo PPGCR da UMESP. Professor na área de Teologia e História da Fateo/UMESP. Especialista em Ensino de Filosofia pela UFSJ

** Bacharel em Teologia pela Faculdade de Teologia da Universidade Metodista de São Paulo, Licenciado em Filosofia pela PUC-RIO e Pós-graduado em Filosofia pela Universidade Estácio de Sá. Professor de Filosofia da SEEDUC-RJ e da FAETEC-RJ. mestrando em Ciências da Religião Pela UMESP.

Revista Páginas de Filosofia, v. 10, n. 1, p. 173-193, jan.-jun. 2021 


\title{
FORGIVENESS IN THE HUMAN CONDITION: BRIEF PERSPECTIVES on A REINTERPREtation of THE gospel in HanNa ARENDT
}

\begin{abstract}
The present work aims to present the notion of forgiveness that Hannah Arendt develops in chapter 5 of the book The Human Condition, in particular, in the subchapter "The irreversibility and the power to forgive". For Arendt, Jesus of Nazareth was the discoverer of the role of forgiveness in the arena of public space. Before presenting the reasons why Arendt mentions some New Testament texts, it will be necessary to understand the political context that drove her to write: the discovery that for totalitarian regimes, men are superfluous. The "death factories" are laboratories that try to modify human nature. Christian theology is requested by Arendt to answer a question found in the last pages of the Origins of Totalitarianism: Is there forgiveness for any type of action? Is there forgiveness for what cannot be punished and punishment for what cannot be forgiven? From the pages of the New Testament, Arendt finds inspiration to reflect on such circumstances.
\end{abstract}

Keywords: Forgiveness. Totalitarianism. Action. Public space. Jesus. Freedom. Politics.

\section{INTRODUÇão}

As crescentes tensões presentes na sociedade brasileira no âmbito das relações entre política e religião, bem como a participação ativa de grupos cristãos dentro desse cenário, motivaram a elaboração desse texto. A crescente disputa de narrativas dentro do espaço público atual tem se mostrado um campo profícuo para uma reflexão acerca dessa tensão. Compreendemos que parte dessas disputas refletem inquietações de natureza teológica. Portanto, ao buscarmos compreender como Arendt - pensadora que conhece bem a tradição política ocidental e a teologia judaico-cristã - interpreta o tema do perdão, elemento fundamental para a reflexão teológica cristã, poderia ser importante para aprofundarmos a compreensão da temática uma análise mais parcimoniosa desse conceito na referida autora.

A partir dessas considerações que nos motivaram ao desenvolvimento desse ensaio, lançamos mão de uma metodologia de pesquisa bibliográfica que sera dividida em quatro seções.

Revista Páginas de Filosofia, v. 10, n. 1, p.173-193, jan.-jun. 2021 
Na primeira seção, salientam-se alguns dados biográficos e bibliográficos que nos ajudam a compreender determinadas características da escrita arendtiana. Num segundo momento, esboçamos uma breve contextualização do tema, especialmente destacando a obra Origens do Totalitarismo - texto responsável por tornar Arendt uma autora conhecida - onde se descrevem os acontecimentos que permitiram o surgimento de ideologias totalitárias na Europa no séc. XX. Em seguida, antes de comentarmos o capítulo 5, outras linhas estarão a serviço da descrição da conjuntura da obra A Condição Humana. Arendt faz uma profunda análise das atividades fundamentais da vida humana para que, em uma delas, seja possível discernir como o perdão exerce um papel fundamental dentro do espaço público.

A terceira parte do artigo tratará propriamente do capítulo 5 onde está o tema central da nossa investigação. Mesmo assim, haverá ainda a necessidade de explicitar o significado da concepção de "ação" e a sua relação com a concepção de perdão na conjuntura da escrita filosófica de Arendt. Na última seção, a argumentação dar-se-á em torno das interpretações que Arendt faz sobre os textos dos Evangelhos que apresentam a doutrina de Jesus de Nazaré sobre o perdão. Essas interpretações estão apresentadas no subcapítulo "A irreversibilidade e o poder de perdoar".

\section{ASPECTOS BIOGRáficos E BIBLIOGRáficos NA ESCRITA DE HANNAh ARENdT ${ }^{1}$}

Poucos autores da tradição Ocidental revelam um estilo marcante de escrita capaz de se confundirem biográfica e bibliograficamente.

1 O entrelaçamento entre o biográfico e o bibliográfico acentua certa visão de Arendt como uma típica personagem da reflexão filosófica do século XX, capaz de promover a fusão do público e do privado em termos de um engajamento cívico coerente e responsável, i.e, de um modo "politicamente produtivo e eticamente apropriado". Em outras palavras, ela encarnaria certa disposição e habilidade de ofertar orientação segura não apenas para estadistas e acadêmicos, mas, sobretudo, para o povo em geral sob a ótica de potencializar caminhos para a edificação de comunidades de iguais. Cf. BOSS, S. Hannah Arendt. In Speaking the Unspeakable in Postwar Germany: Toward a Public Discourse on the Holocaust. Ithaca, NY: Cornell University Press, 2014, p. 87113 (em especial, pag. 87 a 89 onde certo "virtuosismo arendtiano estaria implícito no saber pisar o chão da academia e, ao mesmo tempo, colocar os pés no mundo do diálogo midiático-literário inaugurado no pós-guerra. Disponível em http://www.jstor. org/stable/10.7591/i.ctt1287dgh.9 (acesso em 10/05/2021). 
Em Hannah Arendt, traços desta característica emergem de seus textos como chaves hermenêuticas para uma compreensão mais apurada de seu pensamento. 0 presente artigo busca sinalizar esse aspecto na leitura e interpretação do conceito de perdão, presente na obra $A$ Condição Humana.

Hannah Arendt nasceu em 14 de outubro em Hannover na Alemanha. Filha de judeus de classe média, foi criada em Kognisberg, cidade associada filosoficamente a Emmnuel Kant (1724-1804) que ali estudou e morou.

Arendt perdeu o pai aos 7 anos e sua mãe a levou para morar em Berlim. Entre 1924 a 1929 viveu em Marburgo, em Freiburg e em Heidelberg respectivamente, frequentando cursos de literatura grega, teologia e história. Estudou com influentes intelectuais do século XX como o teólogo Rudolf Bultmann e os filósofos Martin Heidegger e Karl Jaspers. Com esse último, em 1928, foi laureada em Filosofia com uma tese sobre "0 amor em santo Agostinho".

Inicialmente, o interesse teórico de Arendt fora norteado pela filosofia kantiana, pelo existencialismo de Karl Jaspers e, também, Soren Kierkegaard e a filosofia abstrata de Martin Heidegger (FRY, 2010, p.12). Ao fugir do nazismo em 1933, Arendt se refugiou em Paris e ali entrou em contato com a intelectualidade francesa: Alexandre Koyré, Raymond Aron, Jean Paul Sartre e Alexandre Kojeve (REALE, 2008 p. 223). Ainda na França, trabalhou ativamente no envio de crianças judias à Palestina.

Foi presa e internada no Velodrome d'Hiver em 1940 e fugiu em 1941 para os EUA. Escreveu para diversas revistas e ensinou nas Universidades de Berkeley, Princeton, Columbia e, em 1967, lecionou "na filial americana da Escola de Frankfurt", na New School for Social Research em Nova York. Morreu em dezembro de 1975 em Nova York (REALE, 2008, p. 224).

\section{ORIGENS DO TOTALITARISMO}

Segundo Correia (2011, p. 13), as obras A Condição Humana (1958) e As Origens do Totalitarismo (1951) "surgem da mesma disposição para a compreensão, orientada não pela tentativa de negar 
eventos extremos [...] mas pela corajosa determinação para enfrentar a realidade e resistir a ela, seja qual for".

Em as Origens do Totalitarismo encontramos três capítulos que apresentam analiticamente a ideia de que a estrutura social da civilização chegou a seu "ponto de ruptura". No prefácio, Arendt assinala que essa fora escrita "com a convicção de serem passíveis de descobertas os mecanismos que dissolveram os tradicionais elementos do nosso mundo político e espiritual" (ARENDT, 2019 p. 11). Esses "mecanismos" desprovidos de significância dentro do cenário político mundial (questão judaica, o antissemitismo e o Imperialismo) se cristalizaram como agentes catalisadores dos movimentos totalitários na Europa no séc. XX: o Nazismo na Alemanha, o Fascismo na Itália e o Comunismo na Rússia.

"O antissemitismo" (não o simples ódio ao judeu) é caracterizado de duas maneiras distintas: o antissemitismo moderno e o antissemitismo tradicional. Esse último possui conotações religiosas e econômicas, pois eram mais ou menos tolerados em função do papel social que os judeus representavam e desempenhavam (LAFER, 2003, p. 38). Quanto ao antissemitismo moderno, temos o enfraquecimento do Estado-nação e, de modo análogo, "quando os judeus haviam perdido as funções públicas e a influência, e quando nada lhes restava senão sua riqueza" (Arendt, 2019 , p. 27). Condições que corroboram a ideia de Tocqueville quando este, ao analisar a Revolução Francesa, percebe que o ódio das massas aos aristocratas surge quando estes perderam o poder e mantiveram fortuna. Ou seja, perderam o privilégio de oprimir (Arendt, 2019 p. 26). No capítulo dedicado ao "Imperialismo" da obra Origens do Totalitarismo, a emancipação da burguesia na Europa surgida no colonialismo, permitiu o acúmulo de riquezas e o aumento de poder sem a ajuda da aristocracia (FRY, 2010, p. 27). Mesmo as pretensões imperialistas só poderiam existir se na Europa já houvesse, como ideologia política, uma "superstição ou crença" (RACISMO) que justificasse a dominação das colônias. Movimentos pan-nacionais - Arendt chamava de "imperialismo continental" - alimentavam ainda mais a "sociedade burguesa mediante categorias raciais" (FRY, 2010, p. 28).

Logo no prefácio do terceiro capítulo destinado ao Totalitarismo, Arendt indaga: "O que havia acontecido? Por que havia acontecido? 
Como pôde ter acontecido?" Segundo Fry, o totalitarismo é para Arendt algo "novo", um fenômeno sem precedentes e, portanto, distinto de outras formas de tirania (FRY, 2010, p. 31). É assim que Arendt identifica diferenças entre as tiranias e ditaduras clássicas e o totalitarismo. Afinal, segundo a autora, o domínio total é a única forma de governo com a qual não é possível coexistir.

0 totalitarismo funcionaria sem uma nítida hierarquia, uma espécie de ameaça que parece permear todas as relações e, "como sendo uma cebola, na qual cada camada protege o líder", utiliza-se do terror. Contudo, o faz de forma diferente de outros regimes despóticos. Nas tiranias o terror tem função de "amedrontar e suprimir dissensões", enquanto nas ideologias totalitárias o terror é utilizado para "o domínio total das massas, para que sejam perfeitamente obedientes ao Estado" (FRY, 2010, p. 33). Para tanto, os regimes totalitários afirmam que interpretam corretamente as leis da Natureza e da História, por isso, desafiam a legalidade com a pretensão de estabelecerem diretamente o reino de justiça na terra, executam "a lei da História ou da Natureza sem convertê-la em critérios de certo e errado que norteiam a conduta do indivíduo" (ARENDT, 2019, p. 614).

Segundo Fry, Arendt vê nas concepções teleológicas modernas da história a origem deste problema, ou seja, "teorias que afirmam que a história humana é um processo universal que está se movendo em direção a um fim objetivo, ou propósito específico, chamado telos em grego" (FRY, 2010, p. 38). Diferentemente de outros regimes violentos, os regimes totalitários vêem o terror como forma de "realização desses movimentos".

Para Arendt: "O terror é a realização da lei do movimento". Afinal, continua a autora

o seu principal objetivo é tornar possível à força da natureza ou da história propagar-se livremente por toda a humanidade sem o estorvo de qualquer ação humana espontânea. Como tal, o terror procura 'estabilizar' os homens a fim de liberar as forças da natureza ou da história (ARENDT, 2011, p. 618).

Vale ressaltar que Arendt faz menção ao conceito kantiano de "mal radical" que, segundo ela, teria encontrado suas raízes na histó- 
ria a partir de um sistema político onde o bom senso, apesar de gritar desesperadamente, o faz em vão, onde "as massas são submissas e que todo esse gigantesco aparelho de terror é, portanto, supérfluo" (ARENDT, 2011, p. 606). Caso "fossem capazes de dizer a verdade, os governantes totalitários responderiam: o aparelho parece supérfluo unicamente porque serve para tornar os homens supérfluos" (ARENDT, 2011, p. 606).

Será, então, a partir da noção de "mal radical" que Arendt interpretará a importância dos campos de concentração nos regimes totalitários. Os campos de concentração eram laboratórios da experiência totalitária. Experimentou-se ali "a transformação da própria natureza humana, mediante a destruição da espontaneidade de cada indivíduo" (CORREIA, 2011, p. 14).

É importante notar o que está em questão: a dignidade humana. Para Hannah Arendt "o respeito pela dignidade humana implica o reconhecimento de cada indivíduo humano como codificador de um mundo comum" (CORREIA, 2011, p. 14). Mundo negado pelo totalitarismo.

É nesse contexto de transformação da natureza humana e de aniquilação da dignidade humana nos campos de concentração onde Arendt (2012, p. 608) afirma que "os regimes totalitários descobriram, sem saber, que existem crimes que os homens não podem punir e nem perdoar". Tanto o ato de perdoar quanto o de punir estão correlacionados na medida em que ambos se referem à possibilidade de superação de algo que pode reverberar infinitamente (VAZ, 2016, p. 118).

\section{A Condição Humana}

É das Origens do Totalitarismo, em especial, na alteração do final do texto, mediante a incorporação do ensaio "Ideologia e Terror", também de 1958, que se encontra o caminho privilegiado para a compreensão da obra A Condição Humana, e, em especial, o Capítulo 5 intitulado - a "Ação" - onde se encontra a noção de perdão para Arendt (CORREIA, 2011, p. 13).

“O que estamos fazendo?" Essa interrogação é o tema central proposto no prefácio da Condição Humana, considerada por muitos como sua "magnum opus no âmbito da teoria política" (CHIBA, 1995, p. 
506). Essa é a obra mais significativa de Hannah Arendt por, justamente, "traçar determinados elementos de sua filosofia política positiva" e, também, porque foi "destinado a se contrapor à política totalitária" (FRY, 2010, p. 55). É importante frisar que, A Condição Humana, não se limitou a tentar responder sobre o que tornou possível o Totalitarismo e sobre a quebra da tradição do pensamento político Ocidental. Em verdade, pode-se dizer que a obra acabou por se converter "em uma fenomenologia das atividades humanas fundamentais da vida ativa ação, obra e trabalho" 2 (CORREIA, 2011, p 23). Essa investigação surgiu justamente para ser apreciada em contraposição a vida contemplativa que a tradição filosófica priorizou e destacou como estilo de vida fundamental, ao invés de abrir-se a diversidade da opinião na esfera pública. Obviamente, o pensamento não é menos importante do que a política, entretanto, A Condição Humana, é uma tentativa de preencher a lacuna deixada pela tradição quanto a ação política (FRY, 2010, p. 55).

A Condição Humana investigará a vita activa (vida ativa). A intenção de Arendt nessa obra é, portanto, analisar fenomenologicamente a vita activa com o objetivo de compreender a tradição do pensamento político moderno, bem como o desaparecimento da ação e do discurso no âmbito político. Arendt observa que foi justamente esse desaparecimento que proporcionou o surgimento dos movimentos totalitários no séc. XX, mediante o aparecimento de um modo de vida antipolítico. Nesse sentido, Arendt insiste em indicar que o fenômeno totalitário traduz a morte da política, e que a facilidade da sua ascensão e da sua instauração, revelava-se como o sintoma mais evidente da fragilidade da política estruturada em torno do propósito de proteger a vida e o processo de acumulação de recursos para a sua conservação, seu fomento e a ampliação do espectro das necessidades humanas (ARENDT, 2011, p. 43).

2 Na 11 a edição revista e traduzida por Adriano Correia, optou-se por traduzir labor e work por "trabalho" e "obra". A 10a edição traduzida por Roberto Raposo traduziu por "labor" e "trabalho". Outros especialistas e comentaristas consultados em nossa pesquisa bibliográfica utilizaram desta última tradução. Para não correr o risco de imprecisões, as referências utilizadas privilegiarão a $11^{\circ}$ edição em português. Contudo, como opção, serão mantidos os termos originais encontrados na versão em inglês work e labor entre parênteses, independente da opção do comentarista ou tradutor. 
Toda essa questão fica mais clara quando levado em conta que o campo da política para Arendt não é, o da "razão pura" como queria Platão, nem o da "razão prática" como queria Kant. Afinal, o ator nunca é simples 'agente', mas sempre, e ao mesmo tempo, paciente. "O menor dos atos, nas circunstâncias mais limitadas, traz em si a semente da mesma ilimitabilidade, pois basta um ato e, às vezes, uma palavra para mudar todo um conjunto" (LAFER, 2003, p. 59). Desta forma, a opção de Arendt é utilizar o termo vita activa, opondo-se ao pensamento político ocidental, que elegeu a vita contemplativa como o estilo superior da vida do filósofo. Essa superioridade baseia-se "na convicção de que nenhuma obra de mãos humanas pode se igualar em beleza e verdade ao kosmos físico" (ARENDT, 2011, p. 18). 0 próprio cristianismo conferiu "sanção religiosa à vita contemplativa" com a crença de outro mundo, rebaixando assim, a vita activa a uma posição secundária (ARENDT, 2011, p. 19).

Com a expressão vita activa, Arendt pretendeu designar três atividades humanas fundamentais: trabalho (work), obra (labor) e ação (action). "Trabalho (work) é a atividade que corresponde ao processo biológico do corpo humano" (ARENDT, 2011, p. 8). O trabalho (work) assegura não só a sobrevivência do indivíduo como também a vida da espécie. A vida do trabalho (work), tal como Arendt identificava também nos gregos, significa que o indivíduo fica tolhido da vida pública. A condição humana do trabalho (work) é a própria vida. "A obra (labor) é a atividade correspondente a não-naturalidade da existência humana". De acordo com a leitura de Reale "é a práxis não absorvida pelo ciclo vital e que produz um mundo artificial de coisas, claramente distinto do ambiente natural" (REALE, 2008, p. 225).

A obra (labor), produzida por mãos humanas,

fabrica a infinita variedade de coisas cuja soma total constitui o artifício humano [...] o uso adequado delas não causa desaparecimento; elas dão ao artifício humano a estabilidade e a solidez sem as quais não se poderia contar com ele para abrigar a criatura mortal e instável que é o homem (ARENDT, 2011, p. 169). 
Essa distinção natural concede uma espécie de refúgio permanente que, ao não conseguir estruturar e contrastando com as infinitas e cíclicas necessidades supridas pelo trabalho humano, o labor (labor) criado pela fabricação é algo independente dos seres humanos e cria um espaço de durabilidade e de relativa permanência que difere do mundo do trabalho, os quais perecem rapidamente (FRY, 2010, p. 67).

Na fabricação há violência na destruição e manipulação da matéria prima que é utilizada instrumentalmente através do raciocínio lógico. Porém, o que foi fabricado pode ser revertido, se necessário. É a vitória do homo faber que age como senhor na privacidade, visto que precisa estar sozinho para criar e produzir. Como consequência, tem-se uma postura consumista que transforma em mercadoria tudo o que se toca, arruinando tudo. Mais tarde, o trabalhador se encontrará com outros no mercado para intercambiar. Isso faz com que a obra seja mais pública do que o trabalho, mas ainda "não é a esfera do político para ação porque é governada pelos interesses privados e pelo comércio, em contraste com a política" (FRY, 2010, p. 69). A condição humana da obra (labor) é a mundanidade.

É neste contexto que "o espaço público, deixa de ser o espaço da liberdade, no qual os destinos da cidade estão acima dos desejos do indivíduo. Passa a ser o local das reivindicações sociais de cunho privado" (BORTOLOTTI, 2020, p. 368). Com a modernidade e a condução ao esfalecimento das fronteiras entre a esfera pública e privada, há uma substituição das exigências de caráter privado e o labor alcançou a primazia. 0 que era público cedeu espaço a esfera social e ao domínio das massas. 0 consumo "parece ditar as regras do sistema capitalista cuja finalidade consiste em seu próprio sustento, baseado na fabricação e no labor" (BORTOLOTTI, 2020, p. 368).

\section{A Ação}

Como visto na seção anterior, a pluralidade é a condição da ação humana. É justamente no capítulo 5 da Condição Humana que se encontra o tema central da filosofia política de Hannah Arendt. A ação é a única atividade que ocorre diretamente entre os homens, sem a mediação das coisas. 0 trabalho (work) assegura a sobrevivência da 
espécie e do indivíduo, o labor confere permanência e durabilidade à vida humana, já a ação, se empenha em fundar e preservar corpos políticos. Arendt afirma que

Os homens podem perfeitamente viver sem trabalhar, obrigando outros a trabalharem para eles: e podem muito bem decidir simplesmente usar e fruir do mundo de coisas sem lhe acrescentar um só objeto útil [...] Por outro lado, uma vida sem discurso e sem ação deixa de ser uma vida humana, uma vez que já não é vivida entre os homens (ARENDTt, 2011 p. 221).

É com palavras e atos que os homens se apresentam e se inserem nas complexas teias de relações humanas. Uma espécie de segundo nascimento que confirma o aparecimento físico. Arendt, inspirada por Santo Agostinho, compreende que cada ser humano que nasce é um milagre e, após o nascimento, está impelido a agir, pois, como escrevera o próprio filósofo de Hipona na "Cidade de Deus", "para que houvesse um início, o homem foi criado, sem que antes dele ninguém fosse" (ARENDT, 2011, p. 222).

Esse início para Arendt é naturalmente novo em essência, pois assim, "o novo sempre aparece em forma de um milagre. 0 fato de $o$ homem ser capaz de agir significa que se pode esperar dele o inesperado, que ele é capaz de realizar o infinitamente improvável" (ARENDT, 2011, p. 222).

A atividade política para Arendt é a atividade que diferencia o humano dos outros seres vivos, pois, somente através de atos e palavras que os homens se revelam. Segundo Arendt, é "no agir e no falar", que as pessoas mostram quem são, revelam ativamente suas identidades pessoais únicas e, portanto, fazem sua entrada em cena no mundo humano (ARENDT, 2011, p. 222 ). Vale deixar claro, contudo, que para Arendt o humano não possui uma essência, "seria como pular sobre nossas próprias sombras" e que "somente um Deus poderia conhecê-la" (ARENDT, 2011, p. 12). Para Arendt, "o que é revelado através da ação não é uma essência predeterminada de uma pessoa, como se ela fosse um objeto, mas quem, em vez de o que alguém é" (FRY, 2009, p. 70). 
Arendt entende que os gregos (antes de Platão e Aristóteles) honravam a pluralidade e devotavam suas vidas à ação política na pólis. Ela afirma que a polis, não é a cidade-Estado no que tange a sua localização, mas uma organização de pessoas que agem juntos e com um propósito. A ação e o discurso "criam um espaço" que pode ser em qualquer tempo e lugar, onde "eu apareço aos outros e os outros a mim [...] fazem explicitamente seu aparecimento" (ARENDT, 2011, p. 248). "A política baseia-se na pluralidade dos homens" (Arendt, 2002, p. 8). Para que haja essa pluralidade, tem que haver liberdade.

A liberdade, no campo da política, é um problema axiomático (LAFER, 2003, p. 62). É justamente no uso de tal liberdade que, na história do pensamento político, surge o erro por ignorar a inevitabilidade com que os homens se desvelam como sujeitos, como pessoas distintas e singulares, mesmo que inteiramente concentrados na obtenção de um objeto completamente e mundano (ARENDT, 2011, p. 229).

A ação humana não se dá no isolamento. 0 uso da liberdade promove o inevitável e acontece no domínio público, que é o espaço no mundo de que os homens necessitam, para de algum modo, aparecer, portanto, "é obra do homem" em um sentido mais específico que a obra de suas mãos ou do trabalho do seu corpo (ARENDT, 2011 p. 259).

Arendt entende que o ator nunca é simples "agente, mas sempre, e ao mesmo tempo, paciente". Essas consequências são ilimitadas pois

a ação, embora possa provir de nenhures, por assim dizer, atua em meio no qual toda realização se converte em reação de cadeia, e no qual todo processo é causa de novos processos (ARENDT, 2011, p. 238).

O expediente utilizado pelos regimes totalitários é uma chave hermenêutica necessária aqui. Para Bertolloti

a intenção proposta por Arendt é mostrar que a sobrevivência da esfera política está justamente em desarmar a possibilidade de transformar o espaço público num campo apropriado para insuflar o ódio e impedir a convivência baseada no diálogo, ou seja, num espaço democrático (BERTOLLOTI, 2020, p. 366). 
A partir da criação do espaço público, lugar do compartilhamento de ações e palavras, novas relações e realidades aparecem. E assim, é no espaço público e através do agir em conjunto, na convivência entre os homens, que se dá o poder. O poder só acontece onde não há um divórcio entre palavra e ação. "Enquanto o vigor é a qualidade natural de um indivíduo isolado, o poder passa a existir quando os homens agem em conjunto" (ARENDT, 2011, p. 250). A irreversibilidade e a imprevisibilidade, reveladas no espaço público, são características que persistem como "ônus" da ação humana que se estendem no tempo. Para Arendt

Os homens sempre souberam que aquele que age nunca sabe completamente o que está fazendo; que sempre vem a ser 'culpado' de consequências que jamais pretendeu ou previu; que, por mais desastrosas e imprevistas que seja as consequências do seu ato, jamais poderá desfazê-lo; que o processo por ele iniciado jamais se consuma inequivocamente em um único ato ou evento, e que seu verdadeiro significado jamais se desvela para o ator, mas somente à mirada respectiva do historiador, que não age. (ARENDT, 2011, p. 291).

É justamente da espontaneidade das ações humanas no espaço público, cujo nascimento advém da liberdade, da impossibilidade de prever qualquer tipo de consequência (o inesperado, o infinitamente improvável) que surge a seguinte questão: como manter o espaço público diante de condições imprevisíveis e incomensuráveis? Eis o tema deste artigo. Arendt esboça no subcapítulo intitulado "A irreversibilidade e o poder de perdoar" onde discorre sobre o perdão.

\section{A IRREVERSibilidade E O PODER DE PERdoAR}

Na obra póstuma intitulada $O$ que é Política? (1992), percebe-se claramente o que fora apresentado nas seções anteriores. Arendt apresenta a ideia de que a política está baseada na pluralidade dos homens e que o sentido da política é a liberdade (ARENDT, 2002, p. 7). No espaço público, a liberdade e a espontaneidade, são os fatores inexoráveis que permitem o humano revelar suas idiossincrasias. A redenção para o animal laborans dá-se mediante a capacidade de fazer, 
fabricar e produzir. Já o homo faber encontra a redenção da vida por meio das faculdades inter-relacionadas da ação e do discurso (ARENDT, 2011, p. 294). Quanto à ação e o discurso o procedimento é outro. A incerteza não deve produzir um afastamento do humano e suas interações, pelo contrário, a ousadia da exposição e da diversidade pode ser redimida. Arendt entende que

A redenção possível para a vicissitude da irreversibilidade - da incapacidade de desfazer o que se fez, embora não se soubesse nem se pudesse saber o que se fazia - é a faculdade de perdoar. 0 remédio para a imprevisibilidade, para a caótica incerteza do futuro, está contido na faculdade de prometer e cumprir promessas. As duas formam um par, pois a primeira delas, a de perdoar, serve para desfazer os atos do passado, cujos "pecados"pendem como espada de Dâmocles sobre cada nova geração; e a segunda, o obrigar se através de promessas, serve para instaurar o futuro, que é por definição um oceano de incertezas, ilhas de segurança sem as quais nem mesmo a continuidade, sem falar na durabilidade de qualquer espécie, seria possível nas relações entre os homens (ARENDT, 2011, p. 294).

O perdão é para Arendt um "remédio" utilizado contra alguns efeitos colaterais inevitáveis da ação, uma garantia da sobrevivência da política (BORTOLOTTI, 2020, p. 371). O que se fez não pode ser desfeito, mas, pode ser redimido. 0 perdão está relacionado com os atos passados, contudo, a imprevisibilidade do futuro precisa também de redenção. A promessa é uma tentativa de limitar o imprevisível.

0 perdão liberta. Essa libertação das consequências do passado aumenta a capacidade de agir e a promessa cria ilhas de segurança no oceano das incertezas. Segundo Vaz, a principal característica do perdão é a gratuidade. A origem etimológica da palavra perdão vem do baixo latim:

Trata-se da junção do vocábulo per (que neste caso também denota completamente, total, plenamente ou por inteiro) e donare (que exprime dar, doar ou ceder). Sumariando, a expressão per donare pode ser traduzida adequadamente por "dar completamente". Curiosamente, o significado é semelhante no caso do inglês, já que a palavra forgive é constituída pela junção de for (por ou para) e give (dar). De acordo com 
Antônio Boch-Veciana, a provável origem do termo provém da expressão amarai donc in perdos, expressão utilizada pelos trovadores que se traduz adequadamente por "amarás em troca de nada" (VAZ, 2016, p. 120).

Arendt faz um alerta quanto ao perigo de usar remédios que são exitosos na condição de pluralidade em outras dimensões que não a dos assuntos humanos. Ela faz uma alerta, em especial, quanto "a irreversibilidade e a imprevisibilidade humana no domínio da natureza, onde não há remédios para desfazer o que foi feito" (ARENDT, 2011, p. 297). Preocupação legítima. Infelizmente atual.

0 interesse central do presente artigo encontra-se na afirmação de que, no que tange aos interesses humanos, foi Jesus de Nazaré quem descobriu o perdão. Embora essa "descoberta" tenha ocorrido em um "contexto religioso, não é motivo para levarmos menos a sério em um sentido estritamente secular" (ARENDT, 2001 p. 297). Arendt também critica o fato da tradição ser "altamente seletiva" ao excluir "experiências autênticas" que estão fora do campo tradicional da pesquisa política. Ela percebe que a própria tradição dos ensinamentos de Jesus de Nazaré não estão relacionadas "basicamente com a mensagem religiosa cristã, mas surgiram de experiências da pequena e coesa comunidade de seus seguidores, incluindo a desafiar as autoridades políticas de Israel“ (ARENDT, 2011, p. 298).

"Não é verdade que somente Deus tenha o poder de perdoar". A partir dessa premissa encontrada no texto de Lucas 5:21-42, o perdão está na esfera humana das relações, pois, são os homens que, entre si, devem perdoar " antes que possam esperar serem perdoados por Deus” (ARENDT 2011, p. 298). No âmbito do cristianismo, perdoar constitui um dever. Segundo a nota de rodapé 76 da obra $A$ Condição Humana, entende Arendt:

É o que se afirma enfaticamente em Lucas 5:21-42 (cf. Mateus 9:4-6 ou Marcos 12:7-10) onde Jesus opera um milagre para provar que "o Filho do homem tem sobre a Terra o poder de perdoar pecados", com ênfase em "sobre a Terra". 0 que choca o povo é muito mais sua insistência no "poder de perdoar" que um milagre que ele faz, de modo que "os que comiam ali com eles começaram a dizer entre si: Quem é este que também perdoa pecados? (LC 7:49) (ARENDT, 2011, p. 298). 
Mais uma vez, Arendt faz menção a um texto bíblico: Mateus 18:35. Não há no Evangelho, segundo Arendt, a suposição de que "o homem perdoe porque Deus perdoa" e sim que, "se cada um, no íntimo do coração perdoar, Deus fará o mesmo". Na nota de rodapé 77 da obra A Condição Humana, ela interpretará esse texto de Mateus e, também, os textos Mc 11:25 e Mateus 6:14-15, afirmando que "em todos esses casos, o poder de perdoar é um poder fundamentalmente humano: Deus perdoa "nossas dívidas, assim como nós perdoamos nossos devedores" (ARENDT, 2011, p. 299).

Para Arendt, a tradução dos termos gregos não consegue transmitir adequadamente seus respectivos sentidos: aphienai significa despedir libertar e não perdoar. Metanoeim serve para substituir o hebraico Shuv (retornar, voltar sobre os próprios passos) que tem o sentido de mudar de ideia e, a tradução mais adequada para hamartanein seria "transgredir", "errar", "malograr e "extraviar-se”. A insistência de Jesus é pelo fato de que "eles não sabem o que fazem" e por isso, haveria necessidade do perdão.

Na nota 78 da obra A Condição Humana Arendt traduzirá Lucas 17: 3-4 assim: "E se ele transgredir contra ti (...) e (...) procurar-te, dizendo: Mudei de ideia, deves desobrigá-lo (ARENDT, 2011, p. 299). E continua afirmando que "somente com a constante disposição para mudar de ideia e recomeçar pode-se confiar a eles um poder tão grande de começar algo novo" (ARENDT, 2011, p. 300).

0 perdão é o oposto da vingança que atua como re-ação (re-acting). Segundo Vaz (2016, p. 120), “a vingança resulta de uma reação a uma transgressão prévia, no entanto, ela é incapaz de desligar o agente de seu ato". A vingança é uma reação natural, por isso, previsível. 0 perdão, como "exato oposto", é "imprevisível", "uma reação inesperada".

0 ato de perdoar jamais pode ser previsto; é a única reação que atua de modo inesperado, embora seja reação, conserva algo de original da ação. 0 perdão é a única ação que não re-age apenas, mas age de novo e inesperadamente, sem ser condicionada pelo ato que a provocou e que liberta tanto o que perdoa quanto o que é perdoado (ARENDT, 2011, p. 300). Jesus comunica em seus ensinamentos que essa libertação libera tanto o agente quanto o paciente "no inexorável 
automatismo do processo de ação que, por si só, jamais precisa chegar a um fim" (ARENDT, 2011, p. 300). "A violência destruiria o espaço público, uma vez que promoveria um ciclo de reações da mesma forma, violentas" (BERTOLOTTI, 2020, p. 361).

Como alternativa ao perdão, há a punição que não é o seu oposto e, sim, seu correlato. (BERTOLOTTI, 2020, p. 361), Arendt afirma que "ambos têm em comum o fato de que tentam por fim a algo que, sem interferência alguma, poderia prosseguir indefinitivamente" (ARENDT, 2011, p. 301). As ofensas são inevitáveis nas experiências do cotidiano, contudo, algumas delas são imperdoáveis. Ela afirma que os homens não são capazes de perdoar aquilo que não podem punir, o que se revelou imperdoável (ARENDT, 2011, p. 301).

Para Arendt, o conceito kantiano de mal radical, cuja "natureza é tão pouco conhecida" (ARENDT, 2011, p. 301), se apresenta como realidade além da punição e imperdoável por justamente ser incompreensível e estar além dos assuntos humanos. Para HUNT, "com o advento das fábricas da morte, descobrimos que os motivos humanos do egoísmo, o desejo de poder e o ressentimento não são mais capazes de dar sentido ao mundo" (HUNT, 2015 apud BERTOLOTTI, 2020, p. 376). Para Vaz (2020, p. 122), o mal radical, é o resultado do aparecimento de violências inéditas.

Para justificar a impossibilidade de perdão de alguns crimes, Arendt utiliza-se da passagem de Mateus 18:6: "Seria melhor para ele que se atassem ao pescoço uma pedra de moinho e que fosse precipitado ao mar". Para Vaz, o perdão exige uma disposição indefinida para perdoar, contudo, a expressão Bíblica 70 x 7 tem caráter quantitativo. O verbo "escandalizar" de Mateus 18:5 fora utilizado como tradução do vocábulo grego skandalon que significa obstáculo. 0 skandalo se situa fora da possibilidade do perdão:

...tudo o que resta é desejar para o passado - desejar que algo jamais tivesse acontecido. Este mal é absoluto na medida em que é impassível de perdão. Ele se encontra além da capacidade humana de remoção. A punição é metafórica: o suicídio implica dizer que punição alguma é equivalente à falta cometida restando ao próprio indivíduo riscar sua existência. A sentença é problemática, pois Jesus jamais definiu 
algum crime que poderíamos nominar skandalon e ele mesmo intenta ao aceitar sua morte dar o exemplo máximo de sua doutrina, do amor incondicional ao próximo e da generosa capacidade de perdoar mesmo a pior das ofensas (VAZ, 2020, p. 121).

0 perdão e suas relações para Arendt estão no âmbito do pessoal, no qual, a pessoa é perdoada e não seus atos. Ela faz referência ao texto lucano: "Perdoado lhes serão os seus muitos pecados, porque ela amou muito: mas a quem pouco se perdoa, pouco se ama” (7:47), para afirmar que "...é a atual convicção de que só o amor tem o poder para perdoar. Pois o amor é uma das mais raras ocorrências nas vidas humanas"(ARENDT, 2010, p. 301).

Arendt afirma, entretanto, que o amor é não apenas apolítico, mas antipolítico, justamente, pela sua raridade. Por isso ela contesta a suposição cristã que só o amor perdoa não importando o que se tenha feito, pois, dessa maneira, "o perdão teria de ser inteiramente excluído de nossas considerações" (ARENDT, 2010, p. 302). Pelo fato do amor estar na esfera pessoal, "estritamente delimitada", Arendt apresenta o respeito, como "uma amizade sem intimidade ou proximidade" - como a philia politike aristotélica - como o suficiente para motivar o perdão na esfera pública (ARENDT, 2010, p. 302).

\section{CONSIDERAÇões FINAIS}

A violência e o terror perpetrados pelos regimes totalitários no século XX foram inéditos e sem parâmetros dentro da tradição política ocidental. A tentativa de transformar os seres humanos em "supérfluos" em condições não humanas, mostra também a terrível capacidade humana de produzir o mal.

Arendt enxerga na natalidade, no nascimento, o novo, a capacidade de recomeçar, de fazer diferente. Para que isso ocorra, o axioma da política que é a liberdade, não pode ser deposto. A valorização da liberdade dentro do espaço público - um espaço gigante, mas, que não comporta a luta intransigente dos interesses privados - é para Arendt o caminho (inspirado na antiga Pólis Grega) promissor para a valorização da pluralidade humana. Embora Arendt veja na liberdade um caminho saudável, ela sabe da imprevisibilidade das ações humanas: 
os conflitos, as discordâncias e a tentativa de privatização do espaço público necessitarão de um remédio. 0 perdão possui a posologia ideal para ser utilizado em conflitos.

Arendt utilizou-se de categorias da teologia cristã para fundamentar, dentro da esfera política, o perdão como exato oposto da vingança. A vingança é uma reação automática, já o perdão, não pode ser previsto. 0 perdão não reage (re-act). Ele age como algo novo e inesperado (ARENDT, 2010, p. 300).

Nas páginas da obra Origens do Totalitarismo, Arendt afirma que regimes totalitários descobriram, sem querer, que existem crimes imperdoáveis e impuníveis (ARENDT 2012, p. 608). Em acordo com esse preceito, os crimes Totalitários tornaram-se os delimitadores do que seja possível perdoar. Para corroborar esse preceito, Arendt interpreta alguns textos do Novo Testamento, particularmente, textos onde Jesus ensina sua doutrina sobre o perdão, bem como o alcance do perdão.

"Perdoar é uma característica dos fortes, os fracos nunca perdoam", disse Ghandi (apud VAZ, 2016, p. 118). Ao redigirmos esse artigo em período de isolamento social devido à Pandemia do COVID 19, infelizmente testemunhamos pelas várias mídias rompantes de autoritarismo desabrochando em praticamente todo o tyerritório nacional. Desde as eleições de 2018, temas como militarismo, exaltação a torturadores, pedidos de fechamento do STF e do Congresso Nacional, facilitação ao consumo de armas de fogo, destruição da cultura nacional e, também, de biomas como o Pantanal e Floresta Amazônica. Isso tudo - sem contar a corrupção, a negação da ciência, a perseguição de adversários políticos, fundamentalismos, o empobrecimento da classe trabalhadora e a retirada de direitos trabalhistas, etc - demonstra um cenário de profunda crise social. Tal cenário, lamentavelmente, vem sendo apoiado e sustentado por entidades ditas "cristãs".

Arendt nos deixou um alerta: há riscos de governos totalitários permanecerem para sempre conosco. Nesse sentido, se faz necessário resistirmos a tais rompantes de totalitarismo e, ao mesmo tempo, desenvolvermos e cultivarmos a capacidade de perdoar os que desejam trilhar o caminho da violência. Contudo, é indispensável que as correlações entre o perdão e a política continuem suscitando o interesse 
de novas pesquisas e reflexões, o que, aliás, é a proposta deste artigo. É interessante notar que as questões levantadas pela teologia e pela política, além dos mais diversos interesses, promovem um profícuo debate interdisciplinar. Nossa reflexão não possui a pretensão de esgotar o assunto, pelo contrário, ela enseja um desejo de um maior aprofundamento de tais debates.

As questões referentes à política e a religião podem (e devem) ser teorizadas. 0 fato de elas nascerem da realidade concreta do humano, por si só, já as tornam interessantes. Seria imperdoável não continuarmos refletindo sobre elas.

\section{REFERÊNCIAS}

ARENDT. Hannah. Compreender: formação, exílio e totalitarismo (ensaios). Editora Minas Gerais: UFMG: São Paulo: Companhia das Letras, 2008.

. O que é Política? 3.ed. Rio de Janeiro: Bertrand Brasil, 2002.

. Origens do totalitarismo: Antissemitismo, imperialismo, totalitarismo. $11 \mathrm{ed}$. São Paulo: Companhia da Letras, 2019.

A Condição Humana. 11ed. Rio de janeiro: Editora Forense, 2010.

BORTOLOTTI, Ricardo Gião. "Ressentimento e Vingança: Conservação e desagregação do espaço político em Arendt". Griot: Revista de Filosofia, Amargosa, ISSN 2178-1036, (2020): p. 360-379. Disponível em: https://revistaseletronicas.pucrs.br/ojs/index. php/intuitio/article/view/24002. (acesso em 05/05/2021).

BOSS, Sonja. Hannah Arendt. In Speaking the Unspeakable in Postwar Germany: Toward a Public Discourse on the Holocaust (pp. 87-113). Ithaca, NY: Cornell University Press. 2014. Disponível em http://www.jstor.org/stable/10.7591/j.ctt1287dgh.9 (acesso em 10/05/2021).

CHIBA, Shin. "Hannah Arendt on Love and the Political: Love, Friendship, and Citizenship." The Review of Politics 57, no. 3 (1995): 505-35. Disponível em http://www.jstor.org/ stable/1408599. (acesso em 13/05/2021).

FRY, Karin A. Compreender Hannah Arendt. 1. ed. Rio de Janeiro: Editora Vozes, 2010. JÚNIOR, Francisco de Aquino. Teologia e Filosofia: problemas de fronteira. São Paulo: Paulinas, 2018.

LAFER, Celso. Hannah Arendt, Pensamento, Persuação e poder. 2.ed.São Paulo: Paz e Terra, 2003.

Revista Páginas de Filosofia, v. 10, n. 1, p.173-193, jan.-jun. 2021 
REALE, Giovanni et al., História da Filosofia (Vol 6), De Nietzsche à escola de Frankfurt, 2ed.São Paulo. Editora Paulus, 2008.

VAZ, Éden Farias. $O$ Limite do Perdão: Crimes que não se podem punir ou perdoar. Intuitio: Revista de Filosofia, ISSN 1983-4012, (2016): p.118-132. Disponível em: https:// www3.ufrb.edu.br/seer/index.php/griot/article/view/1756. Acesso em setembro de 2020. 